\title{
STRUCTURE AND DIVERSITY OF THE ARBOREAL COMPONENT IN CERRADO SENSU STRICTO IN NORTHERN MINAS GERAIS
}

\author{
Priscila Mendes Lima ${ }^{1}$, Daniel Meira Arruda ${ }^{2 *}$, Rúbia Santos Fonseca ${ }^{3}$, Deicy Danielle Silva ${ }^{4}$ \\ ${ }^{1}$ Universidade Estadual de Montes Claros, Programa de Pós - Graduação em Botânica Aplicada, Montes Claros, Minas Gerais, Brasil - \\ priscilamendesmg@gmail.com \\ 2* Universidade Federal de Minas Gerais, Instituto de Geociências, Belo Horizonte, Minas Gerais, Brasil - arruda.dm@hotmail.com \\ ${ }^{3}$ Universidade Federal de Minas Gerais, Instituto de Ciências Agrárias, Montes Claros, Brasil - rubiafonseca@ hotmail.com \\ ${ }^{4}$ Universidade Estadual de Montes Claros, Programa de Pós - Graduação em Botânica Aplicada, Montes Claros, Minas Gerais, Brasil - \\ deicydanielle@yahoo.com.br
}

Received for publication: 06/06/2019 - Accepted for publication: 25/03/2020

\begin{abstract}
Resumo
Estrutura e diversidade do componente arbóreo em cerrado sensu stricto no Norte de Minas Gerais. Com a rápida mudança do uso da terra do norte de Minas Gerais, grande parte do cerrado já foi convertido em culturas e pouco se sabe sobre a estrutura e diversidade das comunidades remanescentes na região. Diante disso, o presente estudo objetivou caracterizar a estrutura da vegetação arbórea em uma área de cerrado sensu stricto. Para o estudo foram delimitadas 30 parcelas de $20 \mathrm{~m}$ x $20 \mathrm{~m}$ e amostrados os indivíduos arbóreos com diâmetro na altura do solo (DAS $\geq 4,8 \mathrm{~cm}$ ). Foram amostrados 2616 indivíduos pertencentes a 76 espécies de 33 famílias botânicas. A comunidade apresentou densidade de $2181 \mathrm{ind} / \mathrm{ha}$ e área basal de $17,3 \mathrm{~m}^{2} / \mathrm{ha}$. Qualea grandiflora, Terminalia fagifolia e Dimorphandra mollis destacaram-se em relação ao valor de importância. Indivíduos mortos em pé também tiveram destaque na comunidade. Quando comparado a outras comunidades, os valores de diversidade de Shannon $(3,10)$ e equabilidade de Pielou $(0,70)$ indicam que a comunidade se encontra em um estágio intermediário de sucessão. Mesmo com indícios de perturbação, a comunidade comporta espécies com grande importância social e econômica para a população local. O padrão florístico e estrutural dessa comunidade pode ser utilizado como referência para iniciativas de manejo extrativista, restauração e conservação de demais áreas de cerrado na região.
\end{abstract}

Palavras-chave: Fitossociologia, ecologia vegetal, savana, sucessão.

\begin{abstract}
Structure and diversity of the arboreal component in cerrado sensu stricto in northern Minas Gerais. Due to a rapid change in the land use in northern Minas Gerais State, southeastern Brazil, large amounts of cerrado have been converted into crops. There is little information about the structure and diversity of the remaining communities in the region. The present study aimed to characterize the structure of the tree vegetation in a cerrado sensu stricto area. We delimited thirty $20 \mathrm{~m}$ x $20 \mathrm{~m}$ plots and sampled tree individuals with diameter equal to or greater than $4.8 \mathrm{~cm}$ at $30 \mathrm{~cm}$ from the ground level $\left(\mathrm{DGH}_{30}\right)$. We sampled a total of 2616 individuals of 76 species and 33 botanical families. The community showed a density of 2180 ind/ha and a basal area of $17.3 \mathrm{~m}^{2} / \mathrm{ha}$. Qualea grandiflora, Terminalia fagifolia, and Dimorphandra mollis showed high importance values. Standing dead individuals stood out in the community. The Shannon diversity index (3.10) and Pielou's evenness (0.70) indicate that the community is in an intermediate stage of succession in comparison with others. Despite the signs of disturbance, the community still includes species of great social and economic importance for the local population. This community's floristic and structural patterns can be used to reference extractive management, restoration, and conservation initiatives of other cerrado areas in the region.
\end{abstract}

Keywords: Phytosociology, plant ecology, savanna, succession.

\section{INTRODUCTION}

The Cerrado Biome covers more than $25 \%$ of the Brazilian territory, comprising 2,036 $\mathrm{M} \mathrm{km}^{2}$. However, $73 \%$ of its extension is already anthropized (INPE, 2018). This biome is likely to be modified entirely by 2030 if the occupation trends remain at an annual loss of $22 \mathrm{k} \mathrm{km}^{2}$ (MACHADO et al., 2004). In the face of this threat, the Cerrado was elevated to the category of priority global "hotspot" for biodiversity conservation (MYERS et al., 2000; DURIGAN et al., 2011), not only due to the diversity it harbors but also because only $8.1 \%$ of its territory is under environmental protection in Brazil.

The northern Minas Gerais State stands out ecologically as a transition of three phytogeographic domains: Cerrado, Atlantic Forest, and Caatinga. After the inclusion of this region in the Superintendence for the Development of the Northeastern Region (SUDENE, acronym in Portuguese) operational area, there was a rapid change in the natural vegetation cover, with irrigated crops, industrialization, and reforestation projects for charcoal (ESPÍRITO SANTO et al., 2009). As soon as the SUDENE incentives were discontinued, many areas were abandoned, resulting in large tracts of degraded pastureland and remnants of native vegetation dominating

FLORESTA, Curitiba, PR, v. 51, n. 1, p. 061-069, jan/mar 2021.

Lima, P. M. et.al.

ISSN eletrônico 1982-4688

DOI: 10.5380/rf.v51 i1. 67302 
the landscape. However, the deforestation in the Cerrado persisted for many years. Between 2000 and 2015 , suppression rates exceeded natural regeneration by twice. (ESPÍRITO SANTO et al., 2016). Approximately 42.4\% of the original cerrado cover of the region has already been converted to human use. The deforestation rate of 2.8\%/year surpassed that observed in the Amazon Basin (ESPÍRITO SANTO et al., 2016). This threat implies diversity loss and decreased ecosystem services, such as the water supply to a region with a marked water deficit.

Conservation policies and sustainable use of cerrado resources must be strengthened to minimize such losses. A central point of this issue is the knowledge of natural vegetation and its importance for traditional populations, whose subsistence and livelihood depend on available resources. (LIMA et al., 2012). In this context, several studies on the structure and diversity of the arboreal component of the cerrado sensu stricto (hereafter s.s.) are available in the literature (NETTESHEIM, 2010). However, there is little information about the communities in northern Minas Gerais State (see NERI et al., 2007; COSTA et al., 2010; SANTOS et al., 2010). Thus, the present study aims to characterize the tree vegetation structure in the cerrado s.s. in northern Minas Gerais to generate support for conservation, restoration, and sustainable management strategies. Comparing this cerrado with those of other regions allows the implementation of similar restoration, conservation, and management practices (NETTESHEIM, 2010; PEREIRA et al., 2016).

\section{MATERIAL AND METHODS}

\section{Study area}

The study was carried out in the municipality of Montes Claros, Minas Gerais State, southeastern Brazil in the Area of Experimentation and Training in Agroecology at the Alternative Agriculture Center (AEFA CAA/NM, acronym in Portuguese), located at kilometer 35 of the highway BR 135 (Figure 1). The study area corresponds to a remnant of cerrado s.s. with over 20 years of regeneration, totaling approximately 10 ha $\left(16^{\circ} 25^{\prime} 33.54^{\prime \prime} \mathrm{S}\right.$ and $\left.44^{\circ} 02^{\prime} 08.11^{\prime} \mathrm{W}\right)$. The prevailing climate is tropical savanna with dry winters and humid summers (Aw sensu Köppen).
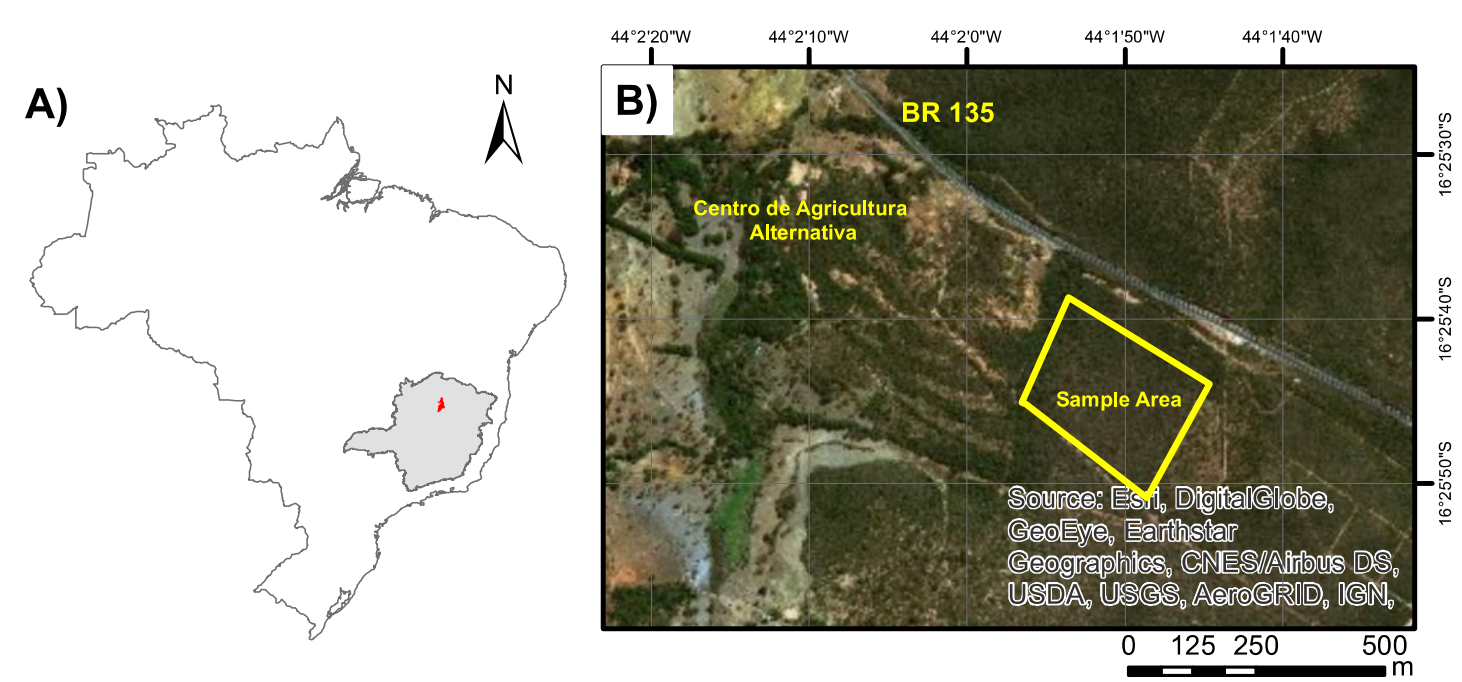

Figure 1. Location of the study area in northern Minas Gerais State (A) and satellite image of cerrado sensu stricto in the Area of Experimentation and Training in Agroecology at the Alternative Agriculture Center (B).

Figura 1. Localização da área de estudo no norte do estado de Minas Gerais (A) e imagem de satélite do cerrado sensu stricto na Área de Experimentação e Formação em Agroecologia do Centro de Agricultura Alternativa (B).

\section{Data collection}

We sampled thirty $20 \times 20 \mathrm{~m}\left(400 \mathrm{~m}^{2}\right)$ plots systematically spaced by $10 \mathrm{~m}$, totaling $1.2 \mathrm{ha}$. We sampled all tree individuals with a trunk diameter greater than $4.8 \mathrm{~cm}$, including dead standing trees. We took measurements at $30 \mathrm{~cm}$ from the ground level. $\left(\mathrm{DGH}_{30} \geq 4.8\right)$. We used a measuring tape to measure diameters and a graduated stick to indicate tree height. We identified the species in the field or through the consultation of herbaria and specialized literature. Voucher material was deposited in the MCCA Herbarium of the Institute of Agricultural Sciences of the Federal University of Minas Gerais.

FLORESTA, Curitiba, PR, v. 51, n. 1, p. 061-069, jan/mar 2021.

Lima, P. M. et.al.

ISSN eletrônico 1982-4688

DOI: $10.5380 /$ rf.v51 i1. 67302 


\section{Data analysis}

We calculated the tree component structure using the parameters: frequency, density, absolute and relative dominance, importance value (MORO; MARTINS, 2011), height, and abundance. We also calculated the Shannon diversity index (H') and Pielou's evenness (J') (MAGURRAN, 2013). We used a script from Cristo and Higuch (2012) for these calculations. We plotted the rarefaction (interpolation) and prediction (extrapolation) curves to determine the sample sufficiency, simulating twice the sample of individuals (CHAO et al., 2014). We used the Hill number method ( $q=0$; species richness) and bootstrap to calculate the standard error with 1,000 randomizations in the iNEXT package (HSIEH et al., 2016). The data were processed using the $\mathrm{R}$ software (R CORE TEAM, 2017).

\section{RESULTS}

We sampled a total of 2,616 individuals of 76 species and 33 families (Table 1). The average density and basal area were $2,181 \mathrm{ind} / \mathrm{ha}$ and $17.3 \mathrm{~m}^{2} / \mathrm{ha}$, respectively. The rarefaction curve indicated sampling stability, with an increase of only $13 \%$ (10 species) if sampling was doubled (Figure 2).

Table 1. Phytosociological structure of a cerrado sensu stricto in northern Minas Gerais State. N- Individual numbers; BA - Basal area; AD - Absolute Density; AF - Absolute Frequency (\%); ADo - Absolute Dominance $\left(\mathrm{m}^{2} / \mathrm{ha}\right)$ and IV - Importance Value (\%).

Tabela 1. Estrutura fitossociológica de um cerrado sensu stricto no Norte de Minas Gerais. N- Número de indivíduos; BA - Área Basal; AD - Densidade Absoluta; ADo - Dominância Absoluta (m²/ha); AF Frequência Absoluta (\%); IV - Valor de Importância (\%).

\begin{tabular}{|c|c|c|c|c|c|c|c|}
\hline Species & Family & $\mathbf{N}$ & BA & AD & ADo & $\mathbf{A F}$ & IV \\
\hline Qualea grandiflora Mart. & VOCHYSIACEAE & 556 & 4.055 & 463.33 & 3.71 & 100 & 15.16 \\
\hline Dead & - & 394 & 3.347 & 328.33 & 3.07 & 100 & 11.97 \\
\hline Terminalia fagifolia Mart. & COMBRETACEAE & 211 & 2.240 & 175.83 & 2.93 & 100 & 9.4 \\
\hline Dimorphandra mollis Benth. & FABACEAE & 122 & 0.446 & 101.67 & 0.69 & 86.67 & 4.11 \\
\hline $\begin{array}{l}\text { Eriotheca pubescens (Mart. Zucc.) } \\
\text { Schott }\end{array}$ & MALVAVCEAE & 108 & 0.016 & 90 & 0.65 & 70 & 3.6 \\
\hline Eugenia sp & MYRTACEAE & 118 & 0.057 & 98.33 & 0.44 & 80 & 3.51 \\
\hline Qualea parviflora Mart. & VOCHYSIACEAE & 92 & 0.134 & 76.67 & 0.65 & 76.67 & 3.5 \\
\hline Hymenaea stigonocarpa Mart. Hayne & FABACEAE & 42 & 2.010 & 35 & 0.94 & 80 & 3.42 \\
\hline $\begin{array}{l}\text { Guapira graciliflora (Mart. Schmidt) } \\
\text { Lundell }\end{array}$ & NYCTAGINACEAE & 102 & 0.278 & 85 & 0.37 & 86.67 & 3.3 \\
\hline Caryocar brasiliense Cambess. & CARYOCARACEAE & 29 & 2.050 & 24.17 & 0.93 & 56.67 & 2.88 \\
\hline Brosimum gaudichaudii Trécul & MORACEAE & 87 & 0.286 & 72.5 & 0.23 & 83.33 & 2.81 \\
\hline Dalbergia miscolobium Benth. & FABACEAE & 67 & 0.025 & 55.83 & 0.41 & 76.67 & 2.76 \\
\hline Bowdichia virgilioides Kunth & FABACEAE & 57 & 0.168 & 47.5 & 0.35 & 76.67 & 2.53 \\
\hline Machaerium opacum Vogel. & FABACEAE & 56 & 0.107 & 46.67 & 0.38 & 60 & 2.31 \\
\hline Leptolobium dasycarpum Vogel & FABACEAE & 42 & 0.009 & 35 & 0.28 & 60 & 1.96 \\
\hline Aspidosperma tomentosum Mart. & APOCYNACEAE & 33 & 0.005 & 27.5 & 0.09 & 66.67 & 1.61 \\
\hline Guapira noxia (Netto) & NYCTAGINACEAE & 26 & 0.012 & 21.67 & 0.33 & 40 & 1.53 \\
\hline Qualea multiflora Mart. & VOCHYSIACEAE & 36 & 0.055 & 30 & 0.12 & 50 & 1.45 \\
\hline Astronium fraxinifolium Schott & FABACEAE & 39 & 0.096 & 32.5 & 0.15 & 40 & 1.39 \\
\hline Buchenavia tomentosa Eichler & COMBRETACEAE & 28 & 0.153 & 23.33 & 0.27 & 33.33 & 1.34 \\
\hline Copaifera langsdorffi Desf. & FABACEAE & 28 & 0.011 & 23.33 & 0.17 & 40 & 1.27 \\
\hline Roupala montana Aubl. & PROTEACEAE & 20 & 0.012 & 16.67 & 0.08 & 40 & 1.01 \\
\hline Strychnos pseudoquina A. & LOGANIACEE & 15 & 0.006 & 12.5 & 0.16 & 33.33 & 0.99 \\
\hline Tabebuia caraiba (Mart.) Bureau & BIGNONIACEAE & 16 & 0.006 & 13.33 & 0.12 & 30 & 0.88 \\
\hline Duguetia furfuracea (A.St.-Hil.) & ANNONACEAE & 18 & 0.036 & 15 & 0.04 & 36.67 & 0.87 \\
\hline
\end{tabular}

FLORESTA, Curitiba, PR, v. 51, n. 1, p. 061-069, jan/mar 2021.

Lima, P. M. et.al.

ISSN eletrônico 1982-4688

DOI: $10.5380 /$ rf.v51 i1. 67302 
Eugenia dysenterica (Mart.)

Erythroxylum suberosum A.St.-Hil.

Pterodon pubescens (Benth.)

Pouteria torta (Mart.)

Aspidosperma macrocarpon Mart. Zuc.

Tachigali aurea Tul.

Miconia albicans (Sw.)

Plathymenia reticulata Benth.

Magonia pubescens A.St.-Hil.

Pouteria ramiflora (Mart.)

Heteropterys byrsonimifolia A.Juss.

Swartzia macrostachya Benth.

Terminalia argentea Mart.

Myrsine guianensis (Aubl.) Kuntze

Qualea dichotoma (Mart.)

Callisthene microphylla Warm.

Machaerium sp

Tocoyena formosa (Cham. Schltdl.)

K.Schum.

Enterolobium gummiferum (Mart.)

Schefflera vinosa (Cham. Schltdl.)

Frodin

Pseudobombax longiflorum (Mart.)

Manihot caerulescens Pohl.

Hancornia speciosa Gomes

Ouratea hexasperma (A.St.-Hil.)

Kielmeyera speciosa A.St.-Hil.

Byrsonima ligustrifolia A.Juss

Senna cana (Nees Mart.) H.S.

Cybistax antisyphilitica (Mart.)Mart

Vatairea macrocarpa (Benth.)

Byrsonima laxiflora Griseb.

Ind 2

Stryphnodendron adstringens Coville

Copaifera coriacea Mart

Handroanthus ochraceus (Cham.)

Mattos

Agonandra brasiliensis Miers Benth.

\&Hook.F.

Casearia sylvestris $\mathrm{Sw}$.

Ind 1

Lafoensia pacari A.St.-Hil.

Styrax ferrugineus Nees Mart

Syagrus flexuosa (Mart.) Becc.
MYRTACEAE

ERYTHROXYLACEAE

FABACEAE

SAPOTACEAE

APOCYNACEAE

FABACEAE

MELASTOMATACEAE

FABACEAE

SAPINDACEAE

SAPOTACEAE

MALPHIGUIACEAE

FABACEAE

COMBRETACEAE

PRIMULACEAE

VOCHYSIACEAE

VOCHYSIACEAE

FABACEAE

RUBIACEAE

FABACEAE

ARALIACEAE

MALVAVCEAE

EUPHORBIACEAE

APOCYNACEAE

OCHNACEAE

CALOPHYLLACEAE

MALPHIGUIACEAE

FABACEAE

BIGNONIACEAE

FABACEAE

MALPHIGUIACEAE

MYRTACEAE

FABACEAE

FABACEAE

BIGNONIACEAE

OPILIACEAE

SALICACEAE

FABACEAE

LYTHRARACEAE

STYRACEAE

ARECACEAE

\section{5}

0.050

12.5

0.05

$36.67 \quad 0.85$

$\begin{array}{llllll}13 & 0.507 & 10.83 & 0.05 & 36.67 & 0.81\end{array}$

$\begin{array}{llllll}14 & 0.021 & 11.67 & 0.09 & 26.67 & 0.75\end{array}$

$\begin{array}{llllll}15 & 0.053 & 12.5 & 0.14 & 20 & 0.75\end{array}$

$\begin{array}{llllll}12 & 0.005 & 10 & 0.05 & 30 & 0.7\end{array}$

$\begin{array}{llllll}14 & 0.016 & 11.67 & 0.11 & 20 & 0.68\end{array}$

$\begin{array}{llll}15 & 0.032 & 12.5 & 0.05\end{array}$

$23.33 \quad 0.64$

$\begin{array}{llll}8 & 0.002 & 6.67 & 0.06\end{array}$

$16.67 \quad 0.47$

$\begin{array}{llllll}14 & 0.035 & 11.67 & 0.03 & 13.33 & 0.44\end{array}$

$\begin{array}{lllllll}7 & 0.056 & 5.83 & 0.05 & 16.67 & 0.43\end{array}$

$\begin{array}{lllllll}10 & 0.028 & 8.33 & 0.03 & 16.67 & 0.43\end{array}$

$\begin{array}{llllll}6 & 0.012 & 5 & 0.01 & 20 & 0.41\end{array}$

$\begin{array}{llllll}7 & 0.097 & 5.83 & 0.09 & 10 & 0.4\end{array}$

$\begin{array}{llllll}6 & 0.002 & 5 & 0.03 & 16.67 & 0.39\end{array}$

$\begin{array}{llllll}7 & 0.006 & 5.83 & 0.05 & 13.33 & 0.39\end{array}$

$\begin{array}{llllll}10 & 0.018 & 8.33 & 0.04 & 6.67 & 0.3\end{array}$

$\begin{array}{llllll}7 & 0.019 & 5.83 & 0.03 & 10 & 0.3\end{array}$

$\begin{array}{llllll}8 & 0.009 & 6.67 & 0.02 & 10 & 0.29\end{array}$

$\begin{array}{llllll}4 & 0.044 & 3.33 & 0.01 & 13.33 & 0.28\end{array}$

$\begin{array}{llllll}6 & 0.085 & 5 & 0.02 & 10 & 0.27\end{array}$

$\begin{array}{llllll}5 & 0.066 & 4.17 & 0.02 & 10 & 0.25\end{array}$

$\begin{array}{llllll}3 & 0.035 & 2.5 & 0.03 & 10 & 0.24\end{array}$

$\begin{array}{llllll}6 & 0.056 & 5 & 0.03 & 6.67 & 0.23\end{array}$

$\begin{array}{llllll}3 & 0.036 & 2.5 & 0.01 & 10 & 0.21\end{array}$

FLORESTA, Curitiba, PR, v. 51, n. 1, p. 061-069, jan/mar 2021.

Lima, P. M. et.al.

ISSN eletrônico 1982-4688

DOI: $10.5380 /$ rf.v51 i1. 67302 


\begin{tabular}{llllllll} 
Byrsonima coccolobifolia Kunth & MALPHIGUIACEAE & 1 & 0.218 & 0.83 & 0.01 & 3.33 & 0.09 \\
Curatella americana L. & DILLENIACEAE & 1 & 0.002 & 0.83 & 0.01 & 3.33 & 0.08 \\
Ind 4 & - & 1 & 0.007 & 0.83 & 0.01 & 3.33 & 0.08 \\
Ind 5 & - & 1 & 0.006 & 0.83 & 0.01 & 3.33 & 0.08 \\
Annona crassiflora Mart & ANNONACEAE & 1 & 0.006 & 0.83 & 0.01 & 3.33 & 0.07 \\
Aspidosperma pyrifolium Mart. Zucc. & APOCYNACEAE & 1 & 0.010 & 0.83 & 0.01 & 3.33 & 0.07 \\
Amoioua sp & RUBIACEAE & 1 & 0.004 & 0.83 & 0 & 3.33 & 0.07 \\
Ind 3 & - & 1 & 0.002 & 0.83 & 0 & 3.33 & 0.07 \\
Myrcia tomentosa (Aubl.) DC. & MYRTACEAE & 1 & 0.002 & 0.83 & 0 & 3.33 & 0.07 \\
Piptocarpha rotundifolia (Less.) & ASTERACEAE & 1 & 0.011 & 0.83 & 0 & 3.33 & 0.07 \\
Coccoloba brasiliensis Nees Mart. & POLYGONACEAE & 1 & 0.005 & 0.83 & 0 & 3.33 & 0.07 \\
\hline TOTAL & & $\mathbf{2 6 1 6}$ & $\mathbf{1 7 . 3 7}$ & $\mathbf{2 1 8 1}$ & $\mathbf{2 2 1 7}$ & $\mathbf{1 6 . 9 3 6}$ & $\mathbf{1 0 0}$ \\
\hline
\end{tabular}

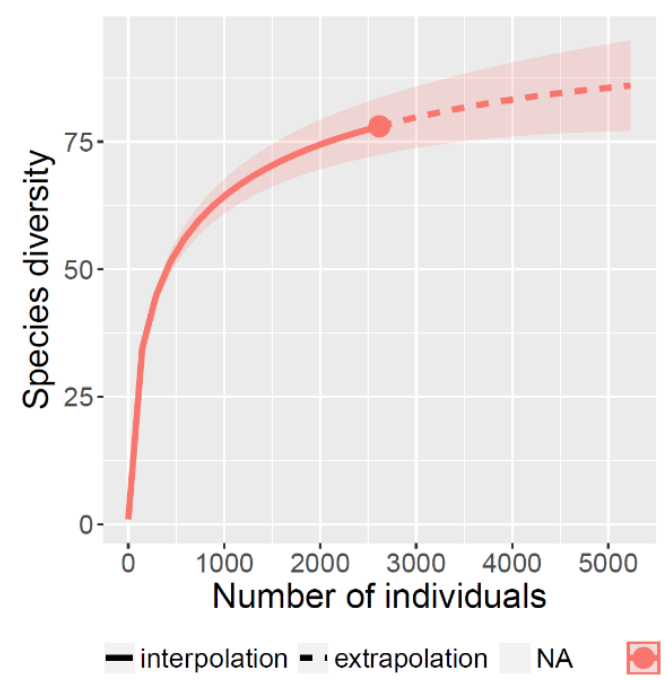

Figure 2. Rarefaction curve (interpolation - continuous line) and species prediction (extrapolation - dotted line) for a cerrado sensu stricto community in northern Minas Gerais State, Brazil.

Figura 2. Curva de rarefação (interpolação - linha contínua) e previsão (extrapolação - linha pontilhada) de espécies para comunidade de cerrado sensu stricto do Norte de Minas Gerais, Brasil.

The most representative families were Fabaceae, with 19 species, Vochysiaceae (5), Myrtaceae (4), Apocynaceae (4), Malphiguiaceae (4), Bignoniaceae (3), Combretaceae (3), Nyctaginaceae (2), Malvaceae (2), Annonaceae (2), and Sapotaceae (2); other families showed one species each. The Shannon diversity index (H') was 3.10 nats/ind. This diversity is similar to those of other cerrado communities in the state, with values ranging from 3.1 to 4.12 nats/ind (Table 2). The Pielou's evenness ( $\mathrm{J}^{\prime}$ ) was 0.70 .

Table 2. Phytosociological studies in cerrado sensu stricto communities in northern Minas Gerais State. ( $\mathrm{S}=$ Richness, BA = Basal area ( $\left.\mathrm{m}^{2} / \mathrm{ha}\right)$, DENS = Density (ind/ha), DIV = Diversity (nats/ind), E = Evenness, AREA = Sampling area (ha), CRIT = Inclusion criterion, $\mathrm{REF}=$ Reference, $\mathrm{CGH}=$ Circumference at ground height, $\mathrm{CBH}=$ Circumference at breast height, $\mathrm{DGH}=$ diameter at ground height and $\mathrm{DBH}=$ diameter at breast height.

Tabela 2. Estudos fitossociológicos em comunidades de cerrado sensu stricto no Norte de Minas Gerais. ( $\mathrm{S}=$ Riqueza; BA = Área Basal $\left(\mathrm{m}^{2} / \mathrm{ha}\right) ;$ DENS = Densidade (ind/ha); DIV = Diversidade (nats/ind); EQ = Equabilidade; ÁREA = Área Amostral (ha); CRIT = Critério de inclusão; REF = Referência; CGH= Circunferência a altura do solo; $\mathrm{CBH}=$ Circunferência a altura do peito; $\mathrm{DGH}=$ Diâmetro a altura do solo e DBH = Diâmetro a altura do peito.

FLORESTA, Curitiba, PR, v. 51, n. 1, p. 061-069, jan/mar 2021.

Lima, P. M. et.al.

ISSN eletrônico 1982-4688

DOI: 10.5380/rf.v51 i1. 67302 


\begin{tabular}{lcccccccl}
\hline SITE & S & BA & DENS & DIV & E & AREA & CRIT & REF \\
\hline Montes Claros & 171 & - & - & 4.12 & 0.8 & 1 & DGH $\geq 3$ & Pereira et al., 2016 \\
Senador Modestino & 91 & 28.93 & 6477 & 3.61 & 0.8 & 0.6 & CGH $\geq 10$ & Neri et al., 2007 \\
Montes Claros & 76 & 17.3 & 2181 & 3.1 & 0.7 & 1.2 & DGH $\geq 4.8$ & Present study \\
Uberlândia* & 74 & 13.63 & 1353 & 3.46 & - & 1 & CBH $\geq 15$ & Alves et al., 2013 \\
Grão Mogol & 54 & - & 1580.58 & 3.27 & 0.84 & - & DBH $\geq 3$ & Costa et al., 2010 \\
Grão Mogol & 48 & - & 1275.51 & 3.13 & 0.87 & - & DBH $\geq 3$ & Costa et al., 2010 \\
Carbonita & 25 & - & 1270 & - & - & 0.4 & CGH $\geq 15$ & Santos et al., 2010 \\
\hline
\end{tabular}

*Cerradão (woodland savanna)

The five species with the highest importance values represented $53 \%$ of the total number of individuals, i.e., half of the total abundance. Qualea grandiflora stood out for occurring in all plots, showing an absolute density of $463 \mathrm{ind} / \mathrm{ha}$ ( $22 \%$ of the total) and a basal area of $4.05 \mathrm{~m}^{2} / \mathrm{ha}$.

The high proportion of standing dead trees indicated disturbances in the community. They occurred in all plots and represented $16.28 \%$ of the relative density and $3.35 \mathrm{~m}^{2} /$ ha of basal area, according to the highest IV (12\% of the total). The diameter distribution curve (Figure 3) corroborates the disturbance premise, presenting an inverted "J" shape, with a predominance of diameters between 5 and $10 \mathrm{~cm}$. The individual height ranged from one meter (Erythroxylum suberosum) to approximately $13 \mathrm{~m}$ (Hymenaea stigonocarpa), with an average of 4.36 $\mathrm{m}$.

A)

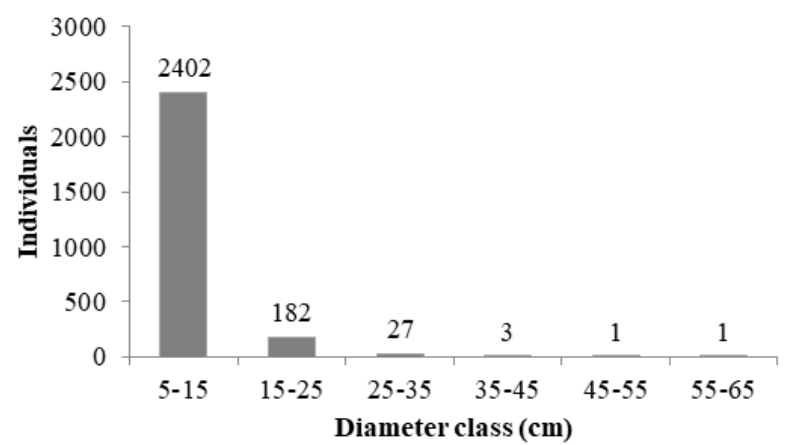

B)

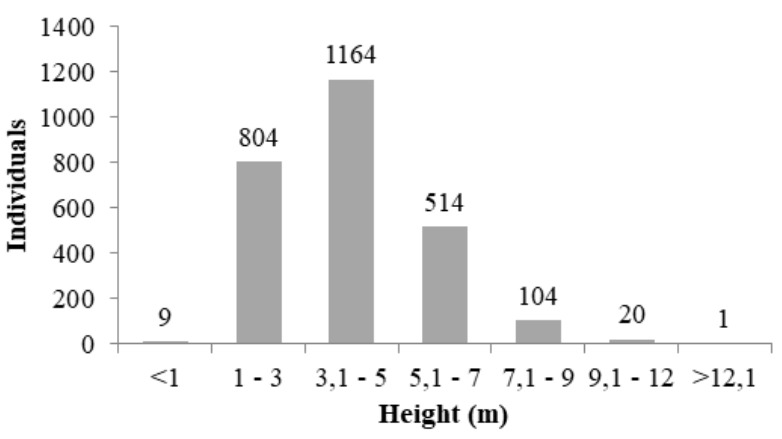

Figure 3. Diameter distribution (A) and height classes (B) of individual trees of the cerrado sensu stricto community in northern Minas Gerais State, Brazil.

Figura 3. Distribuição diamétrica (A) e classes de altura (B) dos indivíduos de comunidade de cerrado sensu stricto no Norte de Minas Gerais, Brasil.

\section{DISCUSSION}

The structural and floristic patterns of the community analyzed portrays the current context of natural landscapes in northern Minas Gerais State, with a high deforestation rate and different succession levels (ESPÍRITO-SANTO et al., 2016). This community presents diversity and structure consistent with a certain disturbance level compared to other cerrado areas in the state, but it is an advanced succession stage and with a flora compatible with other cerrado patches.

The predominance of Fabaceae and Vochysiaceae is evident in different cerrado communities (Table 2). The appearance of Fabaceae as the richest family is common in savanna environments due to the wide plasticity and broad distribution of its species (FINGER; FINGER, 2015). The Shannon index showed an intermediate diversity level in the study area, with evidence of ecological dominance verified by evenness, which was lower than that of other studies (Table 2). Qualea grandiflora showed high importance in most surveys in Minas Gerais (seven out of eight articles surveyed) probably because this species accumulates aluminum and, therefore, its presence is favored in the acid soils of this phytogeographic domain (HARIDASAN, 2000).

FLORESTA, Curitiba, PR, v. 51, n. 1, p. 061-069, jan/mar 2021.

Lima, P. M. et.al.

ISSN eletrônico 1982-4688 
The dominance of standing dead trees in the community surpasses that of other studies in the state. Most of these individual trees corresponded to the species Senna canna and Eugenia punicifolia, with evidence of clonal reproduction at the site (SILVA; PINHEIRO, 2007). This finding shows a post-disturbance successional stage due to succession and the thickening of vegetation, as observed by Cardoso et al. (2009), who found a complete transformation of more open savanna formations into dense cerrado or cerradão after 18 years of disturbance. The inverted " $\mathrm{J}$ " shape found in the diameter classes corroborates the regeneration pattern observed (FINGER; FINGER, 2015).

As for phytosociological parameters, the density value (2.181 ind/ha) was higher than those of different studies in cerrado s.s. (ALVES et al., 2013), but lower than that of the cerrado s.s. of Senador Modestino (NERI et al., 2007). The density found is higher than that estimated for cerrado s.s. (between 664-1396 ind/ha) and compatible with cerradão (960-2082 ind/ha) (FELFILI et al., 1994). However, the criterion adopted in the present study $(\mathrm{DGH} \geq 4.8 \mathrm{~cm}$ ) differs from that suggested for savanna physiognomies (DGH $\geq 3 \mathrm{~cm}$ sensu MORO and MARTINS, 2011). Thus, the density in the present study may have been underestimated, with values close to those found by Neri et al., (2007) in cerrados of the region. Hence, we considered the cerrado s.s. studied here dense, distinguishing it from a cerradão by the presence of a grassy stratum and little canopy superimposition (EMBRAPA, 2019)

Among the species found, we highlight Astronium fraxinifolium (Gonçalo-Alves), Copaifera langsdorffii (Pau-d'óleo), Plathymenia reticulata (Vinhático), Tabebuia aurea (Ipê), and Bowdichia virgilioides (Sucupira preta) due to their structural parameters and timber importance. Other tree species stood out due to their use in local gastronomy and commerce: Caryocar brasiliense (pequi), Byrsonima crassifolia (murici), Hancornia speciosa (mangabeira), and Hymenaea stigonocarpa (Jatobá). At last, some species provide secondary metabolites that can be extracted for medicinal use as antioxidants and anti-inflammatories: Dimorphandra mollis (Fava d'anta), Leptolobium dasycarpum (locally known as unha d'anta), Lafoensia pacari (Pacari), Stryphnodendron adstringens (barbatimão) (LIMA et al., 2012). These species are important for extractivism and increase the potential for conservation and proper management of the area.

\section{CONCLUSIONS}

- We found clear evidence of disturbances in the community. Nevertheless, there was a high density of individuals and species with high economic and social importance for the local population.

- This community's floristic and structural pattern can be used to reference extractive management initiatives for restoration and conservation of other cerrado areas in the region and selection of resistant species, such as Qualea grandiflora.

\section{ACKNOWLEDGMENTS}

We thank the Alternative Agriculture Center of Northern Minas Gerais State (CAA/NM) for allowing us to carry out the study in the Area of Experimentation and Training in Agroecology. We are grateful to Maurício, Gilberto, and their family for the support and hospitality during fieldwork. The Institute of Agricultural Sciences (ICA/UFMG) and the MCCA Herbarium provided us with the available infrastructure. Guilherme C. Oliveira gave invaluable contributions to this manuscript and the translation review.

\section{REFERENCES}

ALVES. H. R,; PRADO JÚNIOR., J.; LOPES. S.; SILVA, P. P.; PEPPE, F. B, SCHIAVINI, I. Fitossociologia e grupos ecológicos da comunidade lenhosa em um remanescente de cerradão em Uberlândia, MG. Caminhos de Geografia, Uberlândia, v. 14, n. 46, p. 236 - 245, 2013.

CARDOSO, E.; MORENO, C. I. M.; BRUNA, M. E.; VASCONCELOS, L. H. Mudanças fitofisionômicas no cerrado: 18 anos de sucessão ecológica na estação ecológica do panga, Uberlândia - MG. Caminhos de Geografia, Uberlândia, v. 10, n. 3, p. 254 - 268, 2009.

CHAO, A.; GOTELli, N. J.; HSIEH, T. C.; SANDER, E. L.; Ma, K. H.; COLWELL, R. K.; ELLISON, A. M. Rarefaction and extrapolation with Hill numbers: a framework for sampling and estimation in species diversity studies. Ecological monographs, v. 84, n. 1, p. 45 - 67, 2014.

CRISTO, A. G; HIGUCH, P. 2012. Script para cálculo de parâmetros estruturais e fitossociológicos da floresta. Disponível em: <https://gist.github.com/ricds/5f84b1ae293c5cae5709> Acessado em: 17/06/2018.

FLORESTA, Curitiba, PR, v. 51, n. 1, p. 061-069, jan/mar 2021.

Lima, P. M. et.al.

ISSN eletrônico 1982-4688

DOI: $10.5380 /$ rf.v51 i1. 67302 
COSTA, F. V.; OLIVEIRA, K. N.; NUNES, Y. R. F.; MENINO, G. C. O.; BRANDÃO, D. O.; ARAÚJO, L. S.; MIRANDA, W. O.; D’ÂNGELO NETO, S. Florística e estrutura da comunidade arbórea de duas áreas de cerrado sentido restrito no Norte de Minas Gerais. Cerne, Lavras, v. 16, n. 3, p. 267 - 281, 2010.

DURIGAN, G.; MELO, A. C. G. de; MAX, J. C. M.; VILlAS BOAS, O. CONTIERI, W. A.; RAMOS, V. S. Manual para recuperação da vegetação do cerrado. São Paulo: Secretaria de Meio Ambiente, 3 ed. 2011,25 p.

EMBRAPA (Empresa Brasileira de Pesquisa Agropecuária, BR). Disponível em: <https://www.embrapa.br/en/cerrados/colecao-entomologica/bioma-cerrado/cerrado-sentido-restrito/cerradodenso> Acesso em 22/11/2019.

ESPÍRITO-SANTO, M. M.; SEVILHA, A. C.; ANAYA, F. C.; BARBOSA, R. S.; FERNANDES, G. W.; SANCHEZ-AZOFEIFA, G. A.; SCARIOT, A. O.; NORONHA, S. E.; SAMPAIO, C. Sustainability of tropical dry forests: two case studies in southeastern and central Brazil. Forest Ecology and Management, v. 258, n. 6, p. $922-930,2009$.

ESPÍRITO-SANTO, M. M.; LEITE, M. E.; SILVA, J. O.; BARBOSA, R. S.; ROCHA, A. M.; ANAYA, F. C.; DUPIN, M. G. V. Understanding patterns of land-cover change in the Brazilian Cerrado from 2000 to 2015. Philosophical Transactions of the Royal Society B., v. 371, 2016.

FELFILI, J. M.; FILGUEIRAS, T. S.; HARIDASAN, M.; SILVA JÚNIOR, M. C.; MENDONÇA, R. C.; REZENDE, A. V. Projeto biogeografia do bioma cerrado: vegetação e solos. Cadernos de Geociências, Salvador, V. 12 , n. 4 , p. $75-166,1994$.

FINGER, Z.; FINGER, F. A. Fitossociologia em Comunidades Arbóreas Remanescentes de Cerrado sensu stricto no Brasil Central. Floresta, Curitiba, v. 45, n. 4, p. 769 - 780, 2015.

HARIDASAN, M. Nutritional adaptations of native plants of the cerrado biome in acid soils. Brazilian Journal Plant Physiology. 2 ed, p.183-195, 2000.

HSIEH, T. C.; MA, K. H.; CHAO, A. iNEXT: an R package for rarefaction and extrapolation of species diversity (Hill numbers). Methods Ecology and Evolution, v. 7, p. 1451 - 1456, 2016.

INMET (Instituto Nacional de Meteorologia, BR). Disponível em: <http:// www.inmet.gov.br> Acesso em 24/04/2019.

INPE (Instituto Nacional de Pesquisas Espaciais, BR). Disponível em: < http://www.inpe.br/noticias/noticia.php?Cod_Noticia=4975> Acesso em 11/11/2019.

LIMA, I. L. P; SCARIOT, A.; MEDEIROS, M. B.; SEVILHA, A. C. Diversidade e uso de plantas do Cerrado em comunidade de Geraizeiros no norte do Estado de Minas Gerais. Acta Botânica Brasileira, São Paulo, v. 26, n. 3, P. 675 - 684, 2012.

MACHADO, R. B.; NETO, R. B. M.; PEREIRA, P. G. P.; CALDAS, F. E.; GONÇALVES, A. D.; SANTOS, S. N.; TABOR, K.; STEININGER, M. Estimativas de perda da área do Cerrado Brasileiro. Brasília: Conservação Internacional, 2004, 26p.

MAGURRAN, A. E. Measuring biological diversity. New Jersey: John Wiley \& Sons, 2013, 264 p.

MORO, M. F.; MARTINS F. R. Métodos de levantamento do componente arbóreo-arbustivo. In: FELFILI, J. M.; ENSENLOHR, P. V.; MELO, M. M, da R. F. de; ANDRADE, L. A. de; MEIRA NETO, J. A. A. Fitossociologia no Brasil: métodos e estudos de caso. Viçosa: Ed. UFV, 2011, 556 p.

MYERS, N.; MITTERMEIER, R. A.; MITTERMEIER, C. G.; DA FONSECA, G. A.; KENT, J. Biodiversity hotspots for conservation priorities. Nature, v. 403, p. $853-858,2000$

NERI, A. V.; MEIRA NETO; J. A. A; SILVA, A; F., MARTINS, S V.; BATISTA M. L. Análise da estrutura de uma comunidade lenhosa em área de cerrado sensu stricto no município de Senador Modestino Gonçalves, Minas Gerais, Brasil. Revista Árvore, Viçosa, v. 31, n. 1, p. 123 - 134, 2007.

NETTESHEIM, F. C.; CARVALHO, D. C.; FONSECA, C. C.; NUNES, R. S.; CAVALCANTI, D. M.; GABRIEL, M. M.; MENEZES, L. F. Estrutura e florística do estrato arbóreo no cerrado sensu stricto de Buritis, Minas Gerais, Brasil. Rodriguésia, Rio de Janeiro, v. 61, n. 4, p. 731 - 747, 2010.

FLORESTA, Curitiba, PR, v. 51, n. 1, p. 061-069, jan/mar 2021.

Lima, P. M. et.al.

ISSN eletrônico 1982-4688

DOI: $10.5380 /$ rf.v51 i1. 67302 
PEREIRA, K. M. G.; CABACINHA, C. D.; ALVES, L. M.; PlAZAS, I. C. V. Composição Florística e Fitossociológica do cerrado sensu stricto no Parque Estadual da Lapa Grande, Montes Claros, MG. Enciclopédia Biosfera, Goiânia, v. 13 n. 24, p. 290 - 305, 2016.

R CORE TEAM. R: A language and environment for statistical computing, version 3.3.3. Vienna, Austria. 2017. $R$ Foundation for Statistical Computing.

SANTOS, L. J. dos; MARMONTEL, C. V. F.; MARTINS, T. M; MELO, A. G. C. de. Fitossociologia de cerrado sensu stricto localizado no município de Carbonita-MG. Revista Científica Eletrônica de Engenharia Florestal, v.15, n.1, p. 77 - 90, 2010.

FLORESTA, Curitiba, PR, v. 51, n. 1, p. 061-069, jan/mar 2021. 